\title{
Changes in Climate Parameters at Wakkanai Area, Which Is Located at Most Northern Part in Japan
}

\author{
Nobuyuki Miyatake, Noriko Sakano, Shoko Murakami
}

Department of Hygiene, Faculty of Medicine, Kagawa University, Kagawa, Japan.

Email: miyarin@med.kagawa-u.ac.jp

Received October $24^{\text {th }}, 2011$; revised November $26^{\text {th }}, 2011$; accepted December $27^{\text {th }}, 2011$

\begin{abstract}
We evaluated the climate change in Wakkanai area, which is located at most northern part and typically rural area in Japan. Climate parameters i.e. atmospheric pressure, air temperature, humidity, velocity, daylight hours and snow fall were obtained from Japan Meteorological Agency. Positive changes in parameters in air temperature, especially mean of the lowest air temperature $(r=0.508, \mathrm{p}<0.0001)$ were noted. In addition, parameters of air temperature in January were significantly and positively correlated with years. However, atmospheric pressure (land) and mean velocity were negatively correlated with years. Global warming was also proved at Wakkanai area, especially in winter, in Japan.
\end{abstract}

Keywords: Wakkanai; Global Warming; Air Temperature; Velocity

\section{Introduction}

Climate change has become public change in the world. We have proved the positive changes in air temperatures in some area in Japan [1,2]. For example, in Takamatsu area, Japan, an increase in $1.8^{\circ} \mathrm{C}$ in mean air temperature was noted for 50 years. However, we could not prove the global warming at Showa base in Antarctica [3] and Hachijo island [1]. In addition, higher air temperature was closely associated with higher total ambulance transports in Japan [4,5]. Therefore, accurate evaluation of the changes in air temperature is urgently required in various sites in Japan.

In this study, we evaluated the changes in climate parameters at Wakkanai areas, which is located at most northern part and typically rural area in Japan.

\section{Methods}

\subsection{Study Area}

Wakkanai area is a city located in Soya, Hokkaido. It is the capital of Soya Sub prefecture and the northernmost city in Japan. It contains Japan's northernmost point, Cape Soya, from which the Russian island of Sakhalin can be seen. As of December 31, 2007, the city has an estimated population of 40,629 and the density of 53.63 persons per $\mathrm{km}^{2}$. The total area is $760.80 \mathrm{~km}^{2}$ (Figure 1, Table 1) [6].

\subsection{Climate Parameters}

Daily meteorological parameters in Wakkanai areas in

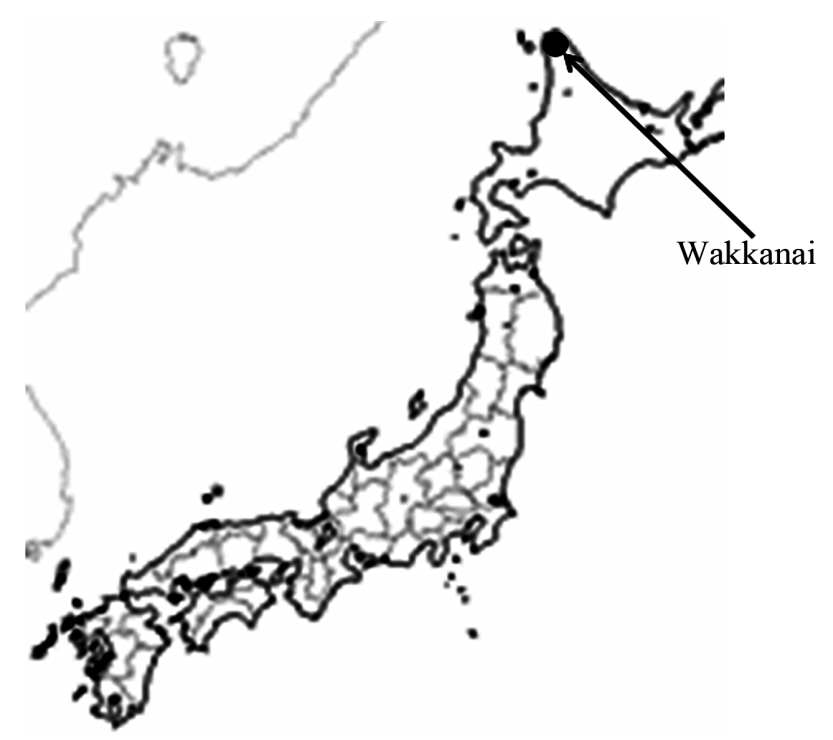

Figure 1. Wakkanai area in Japan (http://www.craftmap.bo x-i.net/map.php).

Japan for the required periods were obtained from Japan Meteorological Agency [7]. The observation spots were located at the central in the area. Daily meteorological parameters i.e. atmospheric pressure (land surface) (hPa), atmospheric pressure (sea surface) (hPa), total precipitation (mm), mean air temperature (Year, January, August: ${ }^{\circ} \mathrm{C}$ ), mean of the highest air temperature (Year, January, August: ${ }^{\circ} \mathrm{C}$ ), mean of the lowest air temperature (Year, January, August: $\left.{ }^{\circ} \mathrm{C}\right)$, the highest air temperature $\left({ }^{\circ} \mathrm{C}\right)$, the lowest air temperature $\left({ }^{\circ} \mathrm{C}\right)$, mean humidity (\%), mean 
Table 1. Parameters at Wakkanai area, Japan.

\begin{tabular}{|c|c|c|c|c|}
\hline & Year & Mean \pm SD & Minimum & Maximum \\
\hline Atmospheric pressure (land) (hPa) & $1950-2010$ & $1010.7 \pm 0.9$ & 1008.9 & 1013.7 \\
\hline Atmospheric pressure (sea) (hPa) & $1938-2010$ & $1011.7 \pm 0.8$ & 1009.9 & 1014.1 \\
\hline Total precipitation (mm) & $1938-2010$ & $1127.8 \pm 192.8$ & 776.5 & 1753.7 \\
\hline Mean air temperature $\left({ }^{\circ} \mathrm{C}\right)$ & $1938-2010$ & $6.5 \pm 0.6$ & 5.0 & 8.2 \\
\hline Mean of the highest air temperature $\left({ }^{\circ} \mathrm{C}\right)$ & 1938-2010 & $9.2 \pm 0.6$ & 7.8 & 10.8 \\
\hline Mean of the lowest air temperature $\left({ }^{\circ} \mathrm{C}\right)$ & $1938-2010$ & $3.9 \pm 0.7$ & 2.4 & 5.6 \\
\hline The highest air temperature $\left({ }^{\circ} \mathrm{C}\right)$ & $1938-2010$ & $27.5 \pm 2.0$ & 23.1 & 31.3 \\
\hline The lowest air temperature $\left({ }^{\circ} \mathrm{C}\right)$ & $1938-2010$ & $-14.2 \pm 2.1$ & -19.4 & -9.6 \\
\hline Mean humidity (\%) & $1938-2010$ & $75.5 \pm 1.9$ & 70.0 & 80.0 \\
\hline Mean velocity (m/s) & $1951-2010$ & $4.7 \pm 0.4$ & 4.1 & 6.2 \\
\hline Daylight hours (hours) & $1938-2010$ & $1579.2 \pm 150.0$ & 1167.7 & 1952.6 \\
\hline Total snowfall (mm) & $1953-2010$ & $429.9 \pm 114.0$ & 189.0 & 705.0 \\
\hline Mean of the highest air temperature in January $\left({ }^{\circ} \mathrm{C}\right)$ & $1938-2010$ & $-3.3 \pm 1.6$ & -6.8 & 0.0 \\
\hline Mean of the highest air temperature in August $\left({ }^{\circ} \mathrm{C}\right)$ & $1938-2010$ & $22.3 \pm 1.9$ & 18.6 & 26.2 \\
\hline Mean of the lowest air temperature in January $\left({ }^{\circ} \mathrm{C}\right)$ & $1938-2010$ & $-7.5 \pm 1.7$ & -11.0 & -3.4 \\
\hline Mean of the lowest air temperature in August $\left({ }^{\circ} \mathrm{C}\right)$ & $1938-2010$ & $17.0 \pm 1.5$ & 13.8 & 20.1 \\
\hline Mean of the mean air temperature in January $\left({ }^{\circ} \mathrm{C}\right)$ & $1938-2010$ & $-5.3 \pm 1.6$ & -8.7 & -1.6 \\
\hline Mean of the mean air temperature in August $\left({ }^{\circ} \mathrm{C}\right)$ & 1938-2010 & $19.4 \pm 1.7$ & 16.3 & 22.6 \\
\hline
\end{tabular}

velocity of the wind $(\mathrm{m} / \mathrm{s})$ and daylight hours (hours) were used for analysis.

\subsection{Statistical Analysis}

Simple correlation analysis was used to test the significance of the linear relationship among continuous variables: $\mathrm{p}<0.05$ was considered to be statistically significant.

\section{Results}

Climate parameters at Wakkanai area were summarized in Table 1. Mean air temperature $(1938-2010)$ was $6.5^{\circ} \mathrm{C}$ $\pm 0.6^{\circ} \mathrm{C}$

We investigated the changes in climate parameters (Table 2). Mean air temperature (Year, January), mean of the highest air temperature (Year, January) and mean of the lowest air temperature (Year, January) were significantly and positively correlated with years. The lowest air temperature was also correlated with years. In addition, The correlation coefficient between mean of the lowest air temperature (Year) and years was the highest $(r=$ 0.508, $\mathrm{p}<0.0001$ ) (Figure 2). However, parameters of air temperature in August, atmospheric pressure (sea), the highest air temperature and total snow fall were not significantly correlated with years. Atmospheric pressure (land), total precipitation, mean humidity, mean velocity and daylight hours were weakly and negatively correlated with years (Table 2).
Table 2. Changes in parameters at Wakkanai area, Japan.

\begin{tabular}{|c|c|c|}
\hline & $\mathrm{r}$ & $\mathrm{p}$ \\
\hline Atmospheric pressure (land) (hPa) & -0.454 & 0.0002 \\
\hline Atmospheric pressure (sea) (hPa) & 0.079 & 0.5079 \\
\hline Total precipitation (mm) & -0.256 & 0.0287 \\
\hline Mean air temperature $\left({ }^{\circ} \mathrm{C}\right)$ & 0.415 & 0.0003 \\
\hline Mean of the highest air temperature $\left({ }^{\circ} \mathrm{C}\right)$ & 0.236 & 0.0445 \\
\hline Mean of the lowest air temperature $\left({ }^{\circ} \mathrm{C}\right)$ & 0.508 & $<0.0001$ \\
\hline The highest air temperature $\left({ }^{\circ} \mathrm{C}\right)$ & -0.207 & 0.0783 \\
\hline The lowest air temperature $\left({ }^{\circ} \mathrm{C}\right)$ & 0.400 & 0.0005 \\
\hline Mean humidity (\%) & -0.250 & 0.0328 \\
\hline Mean velocity $(\mathrm{m} / \mathrm{s})$ & -0.456 & 0.0002 \\
\hline Daylight hours (hours) & -0.385 & 0.0008 \\
\hline Total snowfall (mm) & 0.039 & 0.7698 \\
\hline Mean of the highest air temperature in January $\left({ }^{\circ} \mathrm{C}\right)$ & 0.345 & 0.0028 \\
\hline Mean of the highest air temperature in August $\left({ }^{\circ} \mathrm{C}\right)$ & -0.114 & 0.3387 \\
\hline Mean of the lowest air temperature in January $\left({ }^{\circ} \mathrm{C}\right.$ ) & 0.357 & 0.0019 \\
\hline Mean of the lowest air temperature in August $\left({ }^{\circ} \mathrm{C}\right)$ & 0.060 & 0.6116 \\
\hline Mean of the mean air temperature in January $\left({ }^{\circ} \mathrm{C}\right.$ ) & 0.357 & 0.0019 \\
\hline Mean of the mean air temperature in August $\left({ }^{\circ} \mathrm{C}\right)$ & -0.026 & 0.8265 \\
\hline
\end{tabular}




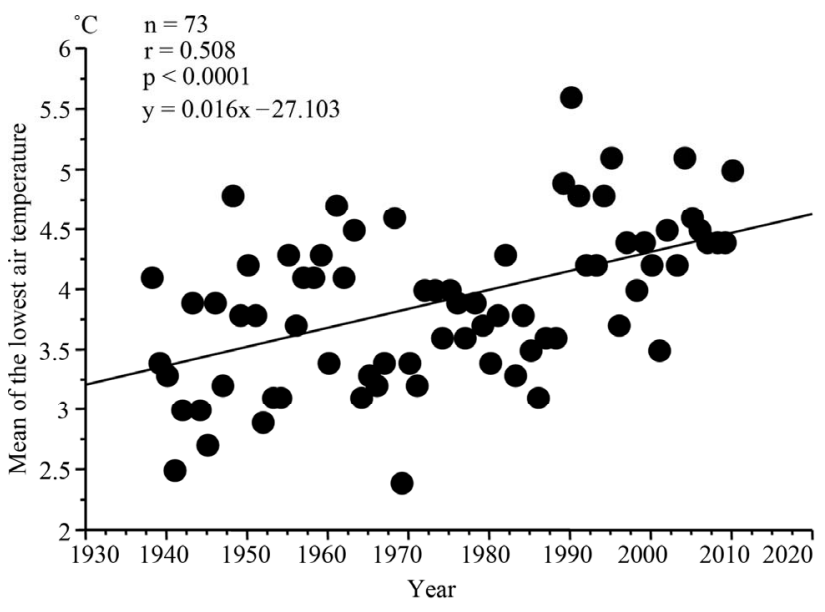

Figure 2. Changes in mean of the lowest air temperature at Wakkanai area, Japan (1938-2010).

\section{Discussion}

Global warming was also proved at Wakkanai area, Japan, especially in parameters of the lowest air temperature and in winter.

The Fourth report of the Intergovernmental Panel on Climate Change (IPCC) at 2007 on climate change has forecast that global warming will have a major impact on health conditions [8]. Global average air temperatures are predicted to increase between $1.8^{\circ} \mathrm{C}$ and $4.0^{\circ} \mathrm{C}$ by the end of this century [8]. Average subsurface temperature profiles in four Asian cities (Tokyo, Osaka, Seoul and Bangkok) were compared and analyzed to evaluate the effects of surface warming [9]. The magnitude of surface warming was the largest in Tokyo $\left(2.8^{\circ} \mathrm{C}\right)$, followed by Seoul, Osaka and Bangkok. In this study, as previous reports $[1,2]$, positive changes in air temperatures were also noted in Wakkanai area, Japan, especially in parameters of the lowest air temperature and in winter. From the single regression line, we have estimated the positive change in the lowest air temperature (Year) was $0.8^{\circ} \mathrm{C}$ for 50 years in Wakkanai area, Japan.

Potential limitation still remains in this study. The changes in parameters of air temperatures, which were noted in Wakkanai area, may not apply for all areas in Japan. Therefore, we could not accurately evaluate the changes in air temperatures in Japan. Second, atmospheric pressure (land), total precipitation, mean humidity, mean velocity and daylight hours were weakly and negatively correlated with years in this area. However, this mechanism is still uncertain in this study. Further studies are required to prove the changes in climate parameters in all over Japan.

\section{Acknowledgements}

This research was support in part by the research grants form FUKUTAKE Science \& Culture Foundation, Japan.

\section{REFERENCES}

[1] N. Miyatake, N. Sakano, S. Murakami, S. Suna, T. Suzue and T. Hirao, "Comparison of the Changes in Temperatures Among Rural, Urban and Metropolitan Areas around the Inland Sea in Japan,” Environmental Monitoring and Assessment, Vol. 181, No. 1-4, 2011, pp. 525-530. doi:10.1007/s10661-010-1846-0

[2] N. Sakano, N. Miyatake, S. Murakami, T. Suzue, T. Hirao and K. Ogino, "Changes in Temperatures in Okayama Area Compared with Different Urbanization Areas, Japan,” Journal of Environmental Protection, Vol. 2, No. 2, 2011, pp. 162-167. doi:10.4236/jep.2011.22018

[3] N. Miyatake, N. Sakano, S. Murakami, T. Suzue and T. Hirao, "Global Warming Was Not Proved at Showa Base in Antarctica," Journal of Environmental Protection, Vol. 2, No. 3, 2011. pp. 323-325. doi:10.4236/jep.2011.23036

[4] N. Miyatake, M. Nakao, N. Sakano, S. Suna, T. Suzue and T. Hirao, "Higher Temperatures Were Closely Associated with Higher Ambulance Transports in Takamatsu Area, Japan,” Journal of Environmental Protection, Vol. 2, No. 1, 2011, pp. 72-75. doi:10.4236/jep.2011.21007

[5] N. Miyatake, N. Sakano, S. Murakami, T. Suzue, T. Yoda, A. Yoshioka and Hirao T, "Air Temperature Was Associated with Ambulance Transports in Osaka Area, Japan,” Health, Vol. 3, No. 9, 2011, 545-548. doi:10.4236/health.2011.39092

[6] Wakkanai City, 2011. http://www.city.wakkanai.hokkai do.jp/main/gaiyo/ (in Japanese)

[7] Japan Meteorological Agency, 2011. http://www.data.jma. go.jp/obd/stats/etrn/index.php?prec_no=11\&prec_ch=\%8 F\%40\%92J\%92n\%95\%FB\&block_no=47401\&block_ch= $\% 92 \mathrm{t} \% 93 \% \mathrm{E} 0 \& \mathrm{year}=\& \mathrm{month}=\&$ day $=\& v i e w=$ (in Japanese)

[8] IPCC, Climate Change 2007, Fourth Assessment Report of the Intergovenmental Panel on Climate Change (IPCC). Cambridge University Press, Cambridge, 2007.

[9] M. Taniguchi, T. Umemura and K. Jago-on, "Combined Effects of Urbanization and Global Warming on Subsurface Temperature in Four Asian Cities," Vadose Zone Journal, Vol. 6, No. 3, 2007, pp. 591-596. doi:10.2136/vzj2006.0094 